Document downloaded from:

http://hdl.handle.net/10251/85526

This paper must be cited as:

Clemments, AM.; Muniesa Lajara, C.; Landry, CC.; Botella Asuncion, P. (2014). Effect of surface properties in protein corona development on mesoporous silica nanoparticles. RSC Advances. 4(55):29134-29138. doi:10.1039/c4ra03277b

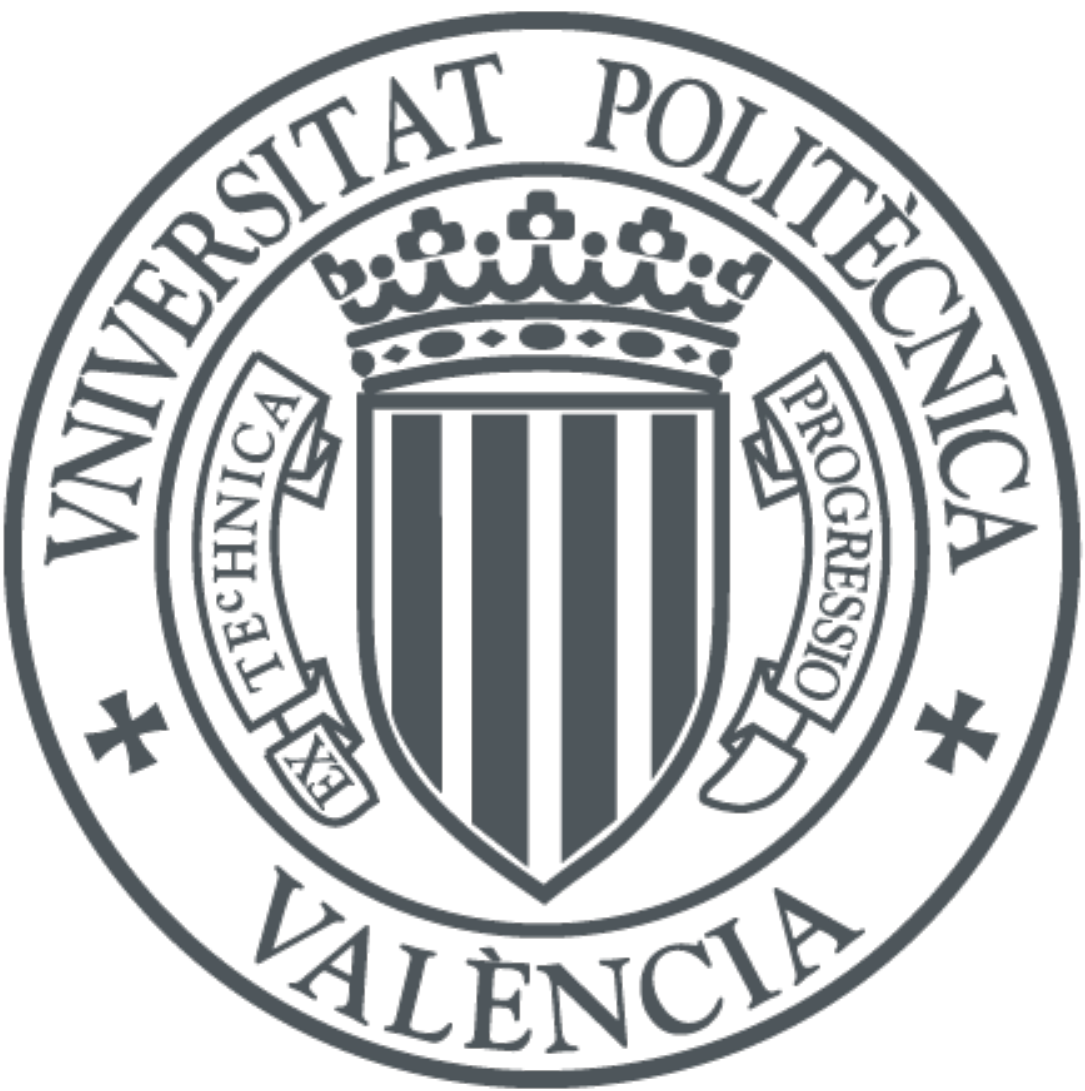

The final publication is available at

http://doi.org/10.1039/c4ra03277b

Copyright Royal Society of Chemistry

Additional Information 

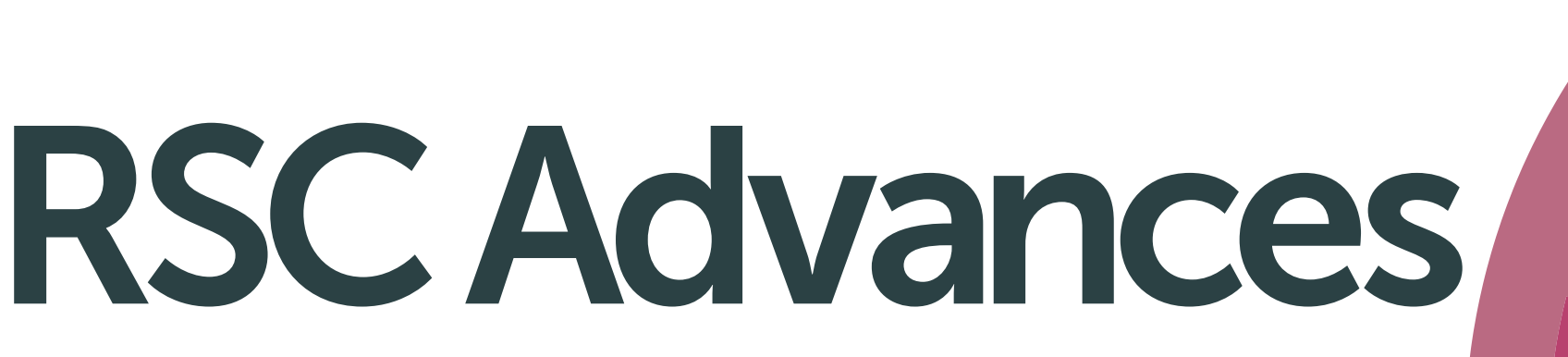

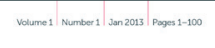

\section{RSC Advances}

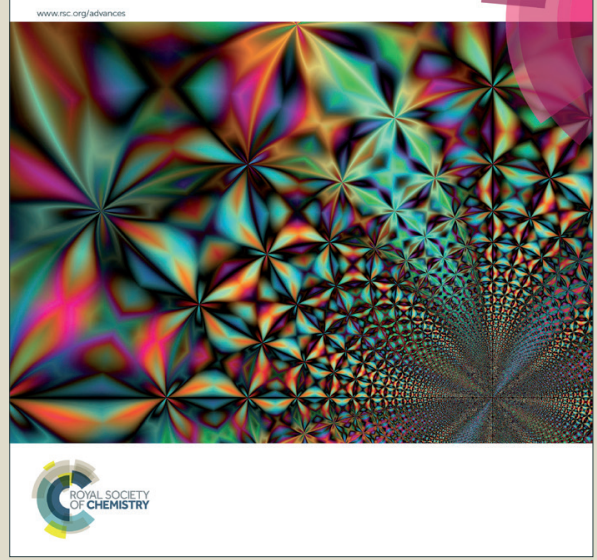

This is an Accepted Manuscript, which has been through the Royal Society of Chemistry peer review process and has been accepted for publication.

Accepted Manuscripts are published online shortly after acceptance, before technical editing, formatting and proof reading. Using this free service, authors can make their results available to the community, in citable form, before we publish the edited article. This Accepted Manuscript will be replaced by the edited, formatted and paginated article as soon as this is available.

You can find more information about Accepted Manuscripts in the Information for Authors.

Please note that technical editing may introduce minor changes to the text and/or graphics, which may alter content. The journal's standard Terms \& Conditions and the Ethical guidelines still apply. In no event shall the Royal Society of Chemistry be held responsible for any errors or omissions in this Accepted Manuscript or any consequences arising from the use of any information it contains. 
Table of Contents figure for

\title{
Effect of surface properties in protein corona development on mesoporous silica nanoparticles
}

\author{
Alden M. Clemments, ${ }^{a}$ Carlos Muniesa,${ }^{b}$ Christopher C. Landry, ${ }^{* a}$ and Pablo Botella $*^{b}$ \\ ${ }^{a}$ Department of Chemistry, University of Vermont \\ 82 University Place, Burlington, VT 05405, USA \\ ${ }^{b}$ Instituto de Tecnología Química (UPV-CSIC), Universidad Politécnica de Valencia, Av. Los Naranjos \\ $s / n, 46022$ Valencia, Spain
}

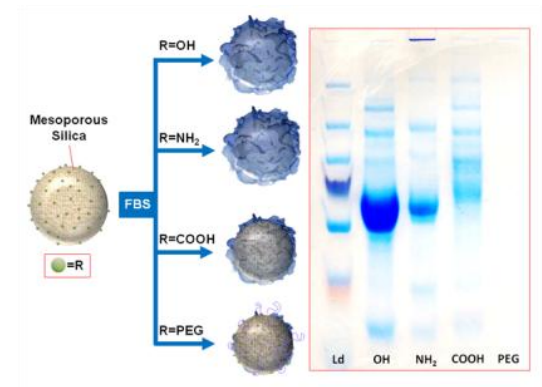




\title{
COMMUNICATION
}

Cite this: DOI: $10.1039 / \times 0 \times x 00000 x$

\section{Effect of surface properties in protein corona development on mesoporous silica nanoparticles}

\author{
Alden M. Clemments, ${ }^{a}$ Carlos Muniesa, ${ }^{b}$ Christopher C. Landry, ${ }^{* a}$ and Pablo \\ Botella*b
}

Received 00th January 2014

Accepted 00th January 2014

DOI: $10.1039 / \times 0 \times x 00000 x$

www.rsc.org/

\begin{abstract}
The composition of the protein corona formed on mesoporous silica nanoparticles with several surface modifications was characterized. Low MW serum proteins were preferentially adsorbed, and PEGylated nanoparticles did not adsorb protein regardless of PEG chain length.
\end{abstract}

Nanomedicine is continuously providing new single and multifunctional alternatives to traditional pharmaceutical delivery and treatment, enhancing both therapeutic activity and selectivity to pathological tissues, as well as providing molecular recognition and biosensing features. ${ }^{1,2}$ Unfortunately, the stability of most nanomaterials in biological fluids is still a challenge to be solved, and the incorporation of stable nanoparticles into the bloodstream provokes a strong reaction with serum proteins, lipids, and small molecules, forming a shell of aggregated compounds known as the

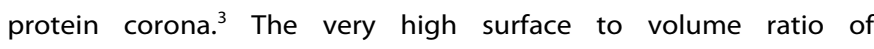
nanomaterials dramatically boosts the adsorption process, changing their surface properties. This corona defines the biological identity of the nanomaterials and determines their final physiological fate. In the case of intravenous (iv) injection, protein adsorption drives nanoparticle uptake by monocytes and macrophages, leading to their distribution to the reticuloendothelial system (RES) and compromising their therapeutic efficacy. ${ }^{4-7}$

Independent of the nature of the nanomaterial, the protein corona grows in a few minutes over the particles and may evolve for several days. ${ }^{8-10}$ It has a complex composition, often consisting of several dozens of proteins. Some of these proteins are loosely bound to particle surface (the "soft corona"), but, so far, most of the studies of this coating have been carried out over a short list of proteins firmly attached to particles forming the "hard corona", as this represents the protein signature of the nanomaterial in a given environment. ${ }^{11-15}$ These studies have shown that the total protein concentration in biological fluids may change the composition of the corona, although, surprisingly, the concentration of a specific protein does not determine its presence in the biological layer (e.g., human serum albumin is the most abundant protein in serum but is actually in minority around nanoparticles). ${ }^{16,17}$ Moreover, the role of targeting molecules decorating the nanoparticle surface depends on this protein covering, as the interaction with specific receptors may be seriously hindered. ${ }^{18}$

Changing nanoparticle properties, such as material, ${ }^{16}$ size, ${ }^{12,19-21}$ and surface chemistry, ${ }^{12,21,22}$ may alter the corona composition. Interestingly, the most widely applied strategy to block nonspecific protein adsorption on nanoparticles is to modify the surface by grafting linear chains of poly(ethylene glycol) (PEG). ${ }^{21,23}$ In fact, different studies support that PEGylation of nanomaterials diminishes interaction with serum proteins, decreasing the rate of phagocytic uptake and increasing blood residence time. ${ }^{24,25}$ Additionally, proteomics analysis has been performed on a wide range of organic and inorganic nanomaterials, such as polystyrene, ${ }^{11,15,16}$ hydrogels, ${ }^{22}$ carbon nanotubes, ${ }^{26}$ gold, ${ }^{9,21}$ SPIONs, $^{27}$ quantum dots, $^{28,29}$ and amorphous silica nanoparticles. ${ }^{16,17,19,20,22}$ However, so far, no investigation has been reported on the protein corona on mesoporous silica nanoparticles (MSNs). In recent years, mesoporous silica materials have been considered to be excellent platforms for drug delivery systems. ${ }^{30-33}$ The large internal porosity of MSNs favors the loading of significant quantities of therapeutic molecules within the pore channels. Furthermore, nanoparticle shape and size, as well as pore structure, can be easily tuned through various synthetic strategies. ${ }^{34,35}$ Finally, the silanol-containing surface can be easily functionalized, introducing additional features that allow for stimuliresponsive controlled drug release. ${ }^{36}$ Shi et $\mathrm{al}^{37}$ highlighted the effect of PEGylation of MSNs on human serum albumin binding and cellular responses, concluding that PEG grafting greatly decreased protein binding to MSNs as well as macrophage uptake. Nevertheless, additional work is needed to completely characterize the protein corona on MSNs, and how it evolves as a function of nanoparticle modification. 
In the present work, we have carried out a complete compositional study of the protein corona adsorbed onto $50 \mathrm{~nm}$ MSNs after incubation ( $1 \mathrm{~h}$ ) in Dulbecco's Modified Eagle's Medium containing $10 \%$ fetal bovine serum (FBS). A proteomic analysis using one-dimensional sodium dodecyl sulfate-polyacrylamide gel electrophoresis (SDS-PAGE) and electrospray liquid chromatography mass spectrometry (LC-MS/MS) has been performed on the protein extract isolated from reacted nanoparticles. Quantitative results for most abundant proteins have been obtained by comparing proteomic distribution with thermogravimetric analysis (TGA) data. Furthermore, we have also investigated the influence of particle surface modification on the protein adsorption process by studying amine and carboxylate-modified MSNs, and we have used different chain length PEG molecules in order to evaluate the effect of PEGylation on particle reactivity.

Highly ordered mesoporous silica nanoparticles (MSNs) were synthesized, with BET surface area about $700-900 \mathrm{~m}^{2} \mathrm{~g}^{-1}$. These MSNs were then used as the base material for further modifications (Fig. 1). The surface areas decreased slightly upon modification with aminoand carboxylate-silanes; however, the modification of the MSNs with PEG chains severely reduced the surface area. This is most likely due to surface shielding and pore blocking effects, consistent with the fact that the surface area for the material modified with a short PEG chain $\left(241 \mathrm{~m}^{2} / \mathrm{g}\right)$ was higher than for the long PEG chain $\left(55 \mathrm{~m}^{2} / \mathrm{g}\right)$. MSNs with average diameters of 50-55 nm (Table 1 and Fig. S1-S2) were obtained with low polydispersion, as characterized by transmission electron microscopy (TEM) and dynamic light scattering (DLS) techniques. Interestingly, the MSNs did not show significant changes in diameter as measured by DLS after exposure to $10 \%$ FBS solution, in contrast with the results of Monopoli et al. who described a 8-12\% increase in the hydrodynamic diameter of amorphous silica nanoparticles after protein adsorption. ${ }^{16}$ However, the latter study used much larger particles ( 200 nm), which likely led to different amounts of protein being adsorbed. ${ }^{20}$

Analysis using TGA, confirmed with elemental analysis, showed that the as-made materials (surface-modified but not yet exposed to protein) contained varying weight percentages of organic material. The total organic content of the amine- and carboxylate-modified MSNs was lower than that of the PEGylated MSNs, but this was primarily due to the increased mass of the PEG silanes. When calculated as mmol silane/g MSN, the trend is reversed, with more of

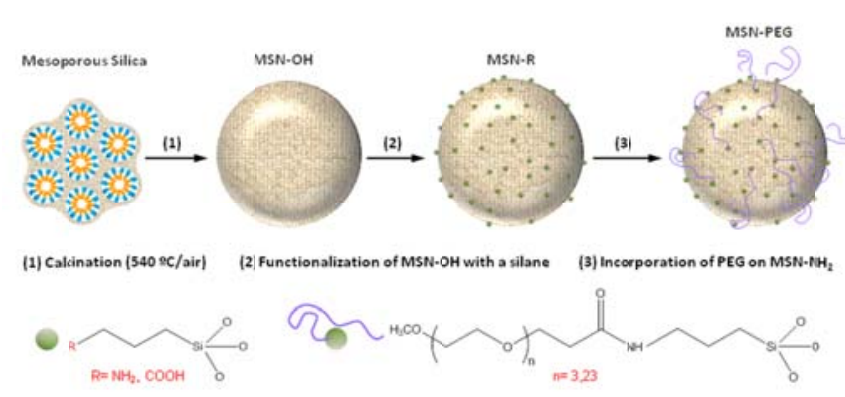

Fig. 1. Synthesis scheme for the materials; used in these experiments.

the smaller silanes than the PEGs, which is consistent with the fact that the smaller silanes are able to access and modify the internal pore surfaces, while the larger PEG silanes primarily modify the external surface and the mouths of the pores, as described above. Finally, when the moles of each sillane are scaled according to the available surface area $\left(S_{B E T}\right)$, which is more consistent with the portion of the MSN that interacts with the protein solution, the values of $\mu \mathrm{mol} / \mathrm{m}^{2}$ are nearly the same, indicating that the surface coverages are similar regardless of the type of modification.

The base material had a zeta potential of $-12.4 \mathrm{mV}$, which is consistent with a bare silica surface in solution. Modification with amine groups led to a less negative zeta potential $(-7.9 \mathrm{mV})$ due to the protonation of amines in the neutral solution used for measurement; the fact that the value is not positive indicates that the surface has not been completely modified. Similarly, MSNs modified with PEG chains showed less negative zeta potentials due to the twostep process used to attach the PEG chains, which involved first modifying the surface with amines followed by reaction with $\mathrm{N}$ hydroxysuccinimide (NHS)-modified $\mathrm{PEG}_{3}$ or $\mathrm{PEG}_{24}$. Thus the zeta potentials of the PEG-modified MSNs reflect the fact that both silanol and amine groups remain on the surface in addition to PEG. As expected, modification with carboxylate groups led to a more negative zeta potential $(-15.4 \mathrm{mV})$.

Upon exposure to $10 \%$ FBS solution, the zeta potentials of the unmodified, $-\mathrm{NH}_{2}$ modified, and $-\mathrm{COOH}$ modified MSNs became substantially less negative, consistent with the formation of a protein corona. The corona led to a shielding effect that altered the surface charge of the particles, which has been reported by other authors using different materials., ${ }^{9,22}$ In the case of the PEGylated MSNs, there was no significant change in zeta potential and therefore surface charge, leading to the conclusion that no significant protein corona

Table 1. Characterization of as-prepared and FBS-exposed MSN samples.

\begin{tabular}{|c|c|c|c|c|c|c|c|c|c|c|c|c|}
\hline \multirow{2}{*}{$\begin{array}{l}\text { Sample } \\
\text { MSN-X }\end{array}$} & \multicolumn{2}{|c|}{$\begin{array}{c}\mathrm{N}_{2} \\
\text { physisorption }\end{array}$} & \multicolumn{2}{|c|}{ Coverage } & \multicolumn{3}{|c|}{$\begin{array}{c}\text { TGA } \\
\text { (wt } \% \text { organic) }\end{array}$} & \multicolumn{2}{|c|}{$\begin{array}{l}\text { Diameter } \\
(\mathrm{nm})^{\mathrm{b}}\end{array}$} & \multicolumn{3}{|c|}{$\begin{array}{c}\zeta \text {-Potential } \\
(\mathrm{mV})\end{array}$} \\
\hline & $\begin{array}{c}S_{B E T} \\
\left(\mathrm{~m}^{2} / \mathrm{g}\right)\end{array}$ & $\begin{array}{l}d_{\text {pore }} \\
(\mathrm{nm})\end{array}$ & $(\mathrm{mmol} / \mathrm{g})$ & $\left(\mu \mathrm{mol} / \mathrm{m}^{2}\right)^{\mathrm{a}}$ & $\begin{array}{c}\text { as } \\
\text { made }\end{array}$ & $\begin{array}{c}\text { FBS- } \\
\text { exposed }^{\text {b }}\end{array}$ & $\begin{array}{c}\text { protein } \\
\text { adsorbed }\end{array}$ & $\begin{array}{l}\text { as } \\
\text { made }\end{array}$ & $\begin{array}{c}\text { FBS- } \\
\text { exposed }^{\text {b }}\end{array}$ & $\begin{array}{l}\text { as } \\
\text { made }\end{array}$ & $\begin{array}{c}\text { FBS- } \\
\text { exposed }^{\text {b }}\end{array}$ & $\Delta$ \\
\hline$-\mathrm{OH}$ & 885 & 3.9 & -- & -- & 8.0 & 18.1 & 10.1 & $53.1 \pm 27.0$ & $50.6 \pm 26.0$ & -12.4 & -4.8 & +7.6 \\
\hline$-\mathrm{NH}_{2}$ & 734 & 3.1 & 2.43 & 3.31 & 8.4 & 22.8 & 14.4 & $51.6 \pm 23.3$ & $54.0 \pm 27.3$ & -7.9 & -4.0 & +3.9 \\
\hline$-\mathrm{COOH}$ & 813 & 3.4 & 2.10 & 2.58 & 14.4 & 16.7 & 2.3 & $50.5 \pm 22.9$ & $51.4 \pm 23.0$ & -15.4 & -10.2 & +5.2 \\
\hline$-\mathrm{PEG}_{3}-\mathrm{OCH}_{3}$ & 241 & 2.7 & 0.87 & 3.61 & 23.5 & 23.3 & -- & $49.9 \pm 23.9$ & $55.6 \pm 27.0$ & -9.4 & -8.7 & +0.7 \\
\hline$-\mathrm{PEG}_{24}-\mathrm{OCH}_{3}$ & 55 & 1.9 & 0.24 & 4.36 & 31.1 & 28.9 & -- & $51.4 \pm 26.8$ & $54.4 \pm 27.0$ & -5.2 & -5.9 & -0.7 \\
\hline
\end{tabular}

${ }^{\text {a }}$ Moles of organic group $(\mu \mathrm{mol} / \mathrm{g})$ divided by $S_{B E T}\left(\mathrm{~m}^{2} / \mathrm{g}\right)$.

${ }^{\mathrm{b}}$ Particles placed in solutions containing $10 \%$ fetal bovine serum in phosphate-buffered saline.

${ }^{\mathrm{c}}$ Hydrodynamic diameter determined by dynamic light scattering. 
had been formed. This was confirmed using thermogravimetric analysis (TGA) on MSNs before and after exposure to $10 \%$ FBS. Unmodified and $-\mathrm{NH}_{2}$ modified MSNs showed significant amounts of adsorbed protein (10.1 and $14.4 \mathrm{wt} \%$ ), with a lesser amount of protein adsorbed by the $-\mathrm{COOH}$ modified MSNs (2.3 wt\%). In contrast, PEGylated MSNs showed no significant protein adsorption. Previous studies used long PEG chains, ${ }^{23,26,37}$ but we show here that even a PEG trimer was sufficient to prevent the formation of a protein corona. This is relevant to the use of porous nanoparticles, because the decrease in surface area and therefore the extent of pore blockage was much smaller for - $\mathrm{PEG}_{3}$ than for $-\mathrm{PEG}_{24}$ modified MSNs.

The protein corona on each type of MSN in these studies was characterized by combining LC-MS and TGA data. Protein was released from the particles for analysis using a typical denaturation process (see Supplementary Information). The amount of protein released by this technique was consistent with the TGA data, as confirmed by the bicinchoninic acid (BCA) assay. While other studies have shown the wide range of proteins that adsorb onto the surfaces of various types of nanoparticles, most of these results have been presented in terms of relative amounts of each. For example, Monopoli et al. ${ }^{16}$ applied a normalization to the spectral counts obtained from LC-MS data that took into account the molecular weight of each protein, but this does not describe the mass of each adsorbed protein. Consequently, in these studies, spectral counts from LC-MS experiments were normalized to obtain the relative percentages of each protein on the surface, and this value was then multiplied by the weight of protein determined by TGA to obtain the mass of each adsorbed protein (Equation 1).

$$
\frac{S p C_{i}}{\sum_{i}^{n} S p C_{i}} \times T G A \times 10
$$

In this equation, $\mathrm{SpC}_{\mathrm{i}}$ is the spectral counts associated with a particular protein, and TGA is the weight percent of adsorbed protein in the particular MSN sample. The factor of 10 is added to bring the units to $\mathrm{mg}$ protein per $\mathrm{g}$ of particles. The first part of the equation is defined as normalized spectral counts, abbreviated NSpC. SpC values and a heat map of the complete set of adsorbed proteins for unmodified, $-\mathrm{NH}_{2}$ modified, and $-\mathrm{COOH}$ modified MSNs are, respectively, shown in Table S1 and Fig. S3, and a subset of the most common proteins, defined as those with NSpC $\times$ TGA of 3.00 or higher, is shown in Table 2. It is apparent that although many proteins are present in $10 \% \mathrm{FBS}$, the subset of adsorbed proteins in each type of MSN's hard corona is much smaller.

More than $86 \mathrm{wt} \%$ of the adsorbed proteins was accounted for by only eight proteins (highlighted in Table 2) in the unmodified MSN sample, and the same proteins accounted for more than $60 \mathrm{wt} \%$ in the $-\mathrm{COOH}$ modified MSN sample although the total amount of adsorbed protein was significantly less. The zeta potential of the surface did not appear to be a significant factor in determining the type of protein adsorbed, because the isoelectric points (pls) of the adsorbed proteins varied between 5.1 and 8.1. The pl values of most of the proteins are below 7, so they are negatively charged at physiological $\mathrm{pH}$. However, deposition on negatively charged nanoparticles does not correlate with protein charge, showing that electrostatic effects alone are not the major driving force regulating MSN-protein interactions. This is consistent with the composition of the protein corona on other particles. ${ }^{20,38}$

Table 2. Most common proteins found on porous $70 \mathrm{~nm}$ nanoparticles with various surface modifications. ${ }^{\text {a }}$

\begin{tabular}{|c|c|c|c|c|c|c|c|c|}
\hline & & & \multicolumn{2}{|c|}{$\mathrm{MSN}-\mathrm{OH}$} & \multicolumn{2}{|c|}{$\mathrm{MSN}-\mathrm{NH}_{2}$} & \multicolumn{2}{|c|}{$\mathrm{MSN}-\mathrm{COOH}$} \\
\hline Protein & $\begin{array}{c}\mathrm{Mw} \\
(\mathrm{kDa})\end{array}$ & $\mathrm{pI}$ & $\mathrm{NSpC}^{\mathrm{b}}$ & $\begin{array}{l}\mathrm{NSpC} \\
\times \mathrm{TGA}^{\mathrm{c}}\end{array}$ & $\mathrm{NSpC}$ & $\begin{array}{l}\mathrm{NSpC} \\
\times \mathrm{TGA}\end{array}$ & $\mathrm{NSpC}$ & $\begin{array}{l}\mathrm{NSpC} \\
\times \mathrm{TGA} \\
\end{array}$ \\
\hline Apolipoprotein A-II & 11 & 8.10 & 0.248 & 25.1 & 0.194 & 27.9 & 0.140 & 3.21 \\
\hline Apolipoprotein C-III & 11 & 5.11 & 0.044 & 4.48 & 0.028 & 4.08 & 0.000 & 0.00 \\
\hline Hemoglobin subunit $\alpha$ & 15 & 8.44 & 0.000 & 0.00 & 0.045 & 6.48 & 0.024 & 0.55 \\
\hline Hemoglobin fetal subunit $\beta$ & 16 & 7.03 & 0.073 & 7.39 & 0.032 & 4.67 & 0.186 & 4.29 \\
\hline Hemoglobin subunit $\beta$ & 16 & 6.74 & 0.061 & 6.16 & 0.000 & 0.00 & 0.096 & 2.21 \\
\hline Apolipoprotein A-I-like & 24 & 5.43 & 0.089 & 9.03 & 0.000 & 0.00 & 0.045 & 1.04 \\
\hline ACTA2 protein-like & 26 & 5.24 & 0.060 & 6.06 & 0.000 & 0.00 & 0.010 & 0.24 \\
\hline Apolipoprotein A-I & 30 & 5.97 & 0.137 & 13.8 & 0.017 & 2.49 & 0.090 & 2.08 \\
\hline Collectin-43 & 34 & 5.12 & 0.000 & 0.00 & 0.026 & 3.74 & 0.000 & 0.00 \\
\hline$\alpha$-2-HS-glycoprotein & 38 & 5.50 & 0.151 & 15.3 & 0.100 & 14.4 & 0.040 & 0.93 \\
\hline Protein AMBP & 39 & 7.62 & 0.000 & 0.00 & 0.061 & 8.82 & 0.000 & 0.00 \\
\hline Actin, $\alpha$ skeletal muscle & 42 & 5.23 & 0.037 & 3.75 & 0.000 & 0.00 & 0.015 & 0.35 \\
\hline LMW Isoform of Kininogen-1 & 48 & 6.62 & 0.000 & 0.00 & 0.025 & 3.58 & 0.000 & 0.00 \\
\hline Serum albumin & 69 & 6.18 & 0.017 & 1.71 & 0.058 & 8.34 & 0.018 & 0.42 \\
\hline Prothrombin (fragment) & 71 & 6.33 & 0.000 & 0.00 & 0.041 & 5.90 & 0.000 & 0.00 \\
\hline Inter- $\alpha$-trypsin inhibitor heavy chain $\mathrm{H} 2$ & 106 & 7.94 & 0.000 & 0.00 & 0.043 & 6.21 & 0.007 & 0.16 \\
\hline $\begin{array}{l}\text { total protein deposit from TGA } \\
\text { (wt } \%)\end{array}$ & & & & 10.1 & & 14.4 & & 2.3 \\
\hline
\end{tabular}

${ }^{\mathrm{a}} \mathrm{MSN}-\mathrm{PEG}_{\mathrm{n}}-\mathrm{OCH}_{3}$ materials did not show a weight loss from TGA and are not included here.

${ }^{\mathrm{b}} \mathrm{NSpC}=$ normalized spectral counts from LC-MS, calculated as described in the text.

${ }^{\mathrm{c}} \mathrm{NSpC} \times \mathrm{TGA}=$ amount of each protein found on particle, expressed as mg protein per $\mathrm{g}$ particles. 
However, it is interesting to note that the molecular weights of these eight proteins were among the smallest of the entire set of identified proteins, with weights all below $38 \mathrm{kDa}$ (Table 2 and Fig. S4)Because these samples all had large internal surface areas, there may be a size-exclusion effect in which larger proteins are prevented from adsorbing in large amounts by the diameter of the pores. This makes sense in light of other studies of the protein corona on dense (nonporous) silica, in which a larger fraction of the adsorbed proteins had higher molecular weights. In the case of $-\mathrm{NH}_{2}$ modified MSNs the protein distribution is more varied. The eight proteins highlighted in Table 2 only account for 37 wt $\%$ of the total amount of adsorbed protein, and more proteins with higher molecular weights were adsorbed. Again, pl does not appear to play an important role here. The reason for this discrepancy could be in the dominant role of surface primary amines in the nonspecific binding of serum proteins on nanoparticles, as has been described in the literature. ${ }^{39,40}$ Additionally, as noted above, the larger surface area of the $-\mathrm{NH}_{2}$ modified MSNs indicate that the pore surfaces are more accessible to proteins, which may allow a wider variety of low molecular weight proteins to be trapped in the pores. Finally, PEGylated samples did not show any protein adsorption by LC-MS or TGA, even in the case of $-\mathrm{PEG}_{3}$ modified particles with surface areas of $241 \mathrm{~m}^{2} / \mathrm{g}$. This confirmed the ability of PEG chains to prevent protein adsorption and therefore to prevent nanoparticle aggregation in biological medium.

In conclusion, we have characterized protein adsorption onto mesoporous silica nanoparticles (MSNs) modified with $-\mathrm{NH}_{2},-\mathrm{COOH}$, $-\mathrm{PEG}_{3}$, and - $\mathrm{PEG}_{24}$ groups as well as onto unmodified MSNs, using LC/MS-MS and TGA to determine the total mass of each protein adsorbed. The results are somewhat different from other studies performed on dense (non-porous) silica nanoparticles. Most of the adsorbed proteins had low molecular weights, and the $-\mathrm{NH}_{2}$ modified MSNs had the largest variety of proteins. The $\mathrm{pl}$ values of the adsorbed proteins were mostly below physiological $\mathrm{pH}$ (7.4), although there was not a strong correlation between $\mathrm{pl}$ and the type of surface modification. Finally, PEGylated particles did not adsorb protein, regardless of chain length.

\section{Acknowledgements}

The authors are thankful for financial support by the Spanish Ministry of Economy and Competiveness (projects SEV-2012-0267, MAT201239290-C02-02 and IPT-2012-0574-300000) and by the University of Vermont.

\section{Notes and references}

${ }^{a}$ Department of Chemistry, University of Vermont, Burlington, VT 05405, U.S.A.

${ }^{b}$ Instituto de Tecnología Química (UPV-CSIC), Av. Los Naranjos s/n, 46022 Valencia, Spain.

$\uparrow$ Electronic Supplementary Information (ESI) available: experimental details, the complete set of LC-MS/MS data, and TEM images. See DOI: $10.1039 / \mathrm{c} 000000 \mathrm{x} /$
1. C. L. Choi and A. P. Alivisatos, Annu. Rev. Phys. Chem. 2010, 61, 369-389.

2. A.Z. Wang, R. Langer and O. C. Farokhzad, Annu. Rev. Med. 2012, 63, $185-198$.

3. M. Mahmoudi, I. Lynch, M. R. Ejtehadi, M. P. Monopoli, F. B. Bombelli, and S. Laurent, Chem. Rev. 2011, 111, 5610-5637.

4. M. P. Monopoli, F. Baldelli Bombelli and K. A. Dawson, Nature Nanotechnol. 2011, 6, 11-12.

5. D.E. Owens III and N. A. Peppas, Int. J. Pharm. 2006, 307, 93-102.

6. S. M. Moghimi, A. C. Hunter and J. C. Murray, Pharmacol. Rev. 2001, 53, 283-318.

7. P. Botella, I. Abasolo, Y. Fernandez, C. Muniesa, S. Miranda, M. Quesada, J. Ruiz, S. Schwartz Jr. and A. Corma, J. Control. Release 2011, 156, 246-257.

8. M. Lundqvist, J. Stigler, T. Cedervall, T. Berggard, M. B. Flanagan, I. Lynch, G. Elia and K. Dawson, ACS Nano 2011, 5, 7503-7509.

9. E. Casals, T. Pfaller, A. Duschl, G. J. Oostingh and V. Puntes, ACS Nano 2010, 5, 3623-3632.

10. A. L. Barran-Berdon, D. Pozzi, G. Caracciolo, A. L. Capriotti, G. Caruso, C. Cavaliere, A. Riccioli, S. Palchetti and A. Lagana, Langmuir 2013, 29, 6485-6494.

11. M. A. Dobrovolskaia, A. K. Patri, J. Zheng, J. D. Clogston, N. Ayub, P. Aggarwal, B. W. Neun, J. B. Hall and S. E. McNeil, Nanomedicine 2009, 5, 106-117.

12. M. Lundqvist, J. Stigler, T. Cedervall, G. Elia, I. Lynch, and K. Dawson, Proc. Natl. Acad. Sci. U.S.A. 2008, 105, 14265-14270.

13. T. Cedervall, I. Lynch, S. Lindman, H. Nilsson, E. Thulin, S. Linse and K. A. Dawson, Proc. Natl. Acad. Sci. U.S.A. 2007, 104, 20502055.

14. D. Walczyk, F. Baldelli Bombelli, M. P. Monopoli, I. Lynch and K. Dawson, J. Am. Chem. Soc. 2010, 132, 5761-5768.

15. I. Lynch, A. Salvati and K. A. Dawson, Nature Nanotechnol. 2009, 4, 546-547.

16. M. P. Monopoli, D. Walczyk, A. Campbell, G. Elia, I. Lynch, F. Baldelli Bombelli and K. A. Dawson, J. Am. Chem. Soc. 2011, 133, 2525-2534.

17. M. Ghavami, S. Saffar, B. A. Emamy, A. Peirovi, M. A. Shokrgozar, V. Serpooshan and M. Mahmoudi, RSC Adv. 2013, 3, 1119-1126.

18. A. Salvati, A. S. Pitek, M. P. Monopoli, K. Prapainop, F. Baldelli Bombelli, D. R. Hristov, P. M. Kelly, C. Aberg, E. Mahon and K. A. Dawson, Nature Nanotechnol. 2013, 8, 137-143.

19. J. Wang, U. B. Jensen, G. V. Jensen, S. Shipovskov, V. S. Balakrishnan, D. Otzen, J. S. Pedersern, F. Besenbacher and D. S. Sutherland, Nano Lett. 2011, 11, 4985-4991.

20. S. Tenzer, D. Docter, S. Rosfa, A. Wlodarski, J. Kuharev, A. Rekik, S. K. Knauer, C. Bantz, T. Nawroth, C. Bier, J. Sirirattanapan, W. Mann, L. Truel, R. Zellner, M. Maskos, H. Schild and R. H. Stauber, ACS Nano, 2011, 5, 7155-7167.

21. C. D. Walkey, J. B. Olsen, H. Guo, A. Emili and W. C. W. Chan, J. Am. Chem. Soc. 2012, 134, 2139-2147.

22. N. P. Mortensen, G. B. Hurst, W. Wang, C. M. Foster, P. D. Nallathamby and S. T. Retterer, Nanoscale 2013, 5, 6372-6380.

23. J. L. Perry, K. G. Reuter, M. P. Kai, K. P. Herlihy, S. W. Jones, J. C. Luft, M. Napier, J. E. Bear and J. M. DeSimone, Nano Lett. 2012, 12, 5304-5310. 
24. T. Niidome, M. Yamagata, Y. Okamoto, Y. Akiyama, H. Takahashi, T. Kawano, Y. Katayama and Y. Niidome, J. Control. Release 2006, 114, 343-347.

25. K. Park, J. Control. Release 2010, 142, 147-148.

26. C. Sacchetti, K. Motamedchaboki, A. Magrini, G. Palmieri, M. Mattei, S. Bernardini, N. Rosato, N. Bottini and M. Bottini, ACS Nano 2013, 7, 1974-1989.

27. A. Jedlovszky-Hajdu, F. Baldelli Bombelli, M. P. Monopoli, E. Tombacz and K. A. Dawson, Langmuir 2012, 28, 14983-14991.

28. C. Röcker, M. Pötzl, F. Zhang, W. J. Parak and G. U. Nienhaus, Nature Nanotechnol. 2009, 4, 577-580.

29. K. Prapainop, D. P. Witter and P. Wentworth Jr., J. Am. Chem.. Soc. 2012, 134, 4100-4103.

30. M. Vallet-Regi, F. Balas and D. Arcos, Angew. Chem.. Int. Ed. 2007, 46, 7548-7558.

31. I. I. Slowing, J. L. Vivero-Escoto, C. W. Wu and V. S. Lin, Adv. Drug Delivery Rev. 2008, 60, 1278-1288.

32. Y. Chen, H. Chen and J. Shi, Adv. Mater. 2013, 25, 3144-3176.

33. D. Tarn, C. E. Ashley, M. Xue, E. C. Carnes, J. I. Zink and J. Brinker, Acc. Chem. Res. 2013, 46, 792-801.

34. B. G. Trewyn, C. M. Whitman and V. S.-Y. Lin, Nano Lett. 2004, 4, 2139-2143.

35. F. Gao, P. Botella, A. Corma, J. Blesa and L. Dong, J. Phys. Chem. B 2009, 113, 1796-1804.

36. J. L. Vivero-Escoto, I. I. Slowing, B. G. Trewyn, V. S.-Y. Lin, Small 2010, 6, 1952-1967.

37. Q. He, J. Zhang, J. Shi, Z. Zhu, L. Zhang, W. Bu, L. Guo and Y. Chen, Biomaterials 2010, 31, 1085-1092.

38. S. Tenzer, D. Docter, J. Kuharev, A. Musyanovych, V. Fetz, R. Hecht, F. Schlenk, D. Fischer, K. Kiouptsi, C. Reinhardt, K. Landfester, H. Schild, M. Maskos, S.K. Knauer and R.H. Stauber, Nature Nanotechnol. 2013, 8, 772-781.

39. M. A. Dobrovolskaia, P. Aggarwal, J. B. Hall, and S. E. McNeil, Mol. Pharmaceutics 2008, 5, 487-495.

40. J. L. Towson, Y.-S. Lin, J. O. Agola, E. C. Carnes, H. S. Leong, J. D. Lewis, C. L. Haynes, and C. J. Brinker, J. Am. Chem. Soc. 2013, 135, 16030-16033. 